\title{
Evidências de imprecisão nas políticas habitacionais brasileiras: o caso de São Paulo
}

\author{
Evidences of imprecision in Brazilian housing policies: the case of São Paulo
}

Tiago Augusto da Cunha, Maristela Siolari da Silva

Universidade Federal de Viçosa (UFV), Departamento de Arquitetura e Urbanismo (DAU), Viçosa, MG, Brasil

\section{Resumo}

Após 2002, novos instrumentos e objetivos foram adicionados à política habitacional nacional, voltados para a inclusão e a equidade social ao propor a garantia de acesso à habitação para a população financeiramente mais carente. Nesse sentido, interessa ao presente estudo investigar a acurácia do Programa Minha Casa, Minha Vida (PMCMV), elucidando se os aportes estão, de fato, atingindo a população mais privada de meios físico-financeiros para adquiri-la. A bibliografia recente aponta o contrário. Presume-se, portanto, que a relação público alvo/público atingido divirja. Para tanto, lança-se mão de dados provenientes da Secretaria Nacional de Habitação (SNH) e da Caixa Econômica Federal (CEF), que esmiúçam o déficit habitacional municipal e os empreendimentos destinados a saná-lo, segundo faixas de renda e localização. Os dados, por sua vez, compreendem os empreendimentos aprovados, não necessariamente executados, até 2013 no Estado de São Paulo. Opta-se por utilizá-lo como recorte territorial, haja vista que apresenta os mais significativos valores absolutos de déficit habitacional da União. Nota-se que a política habitacional brasileira é territorialmente abrangente e correlata à presença do déficit, entretanto persiste a reprodução de desigualdades de acesso à moradia por meio de critérios de renda.

Palavras-chave: Habitação. Demanda. Desigualdade social. Programa Minha Casa, Minha Vida. São Paulo.

\section{Abstract}

New instruments and goals have been recently, and especially after 2002, added to the national housing policy. They have focused on social inclusion and equality by proposing the guarantee of access to housing for the economically less favored classes of the population. In this sense, the present study aimed to investigate the accuracy of the "My House, My Life" Program (MHMLP), in order to elucidate whether the subsidies have in fact benefited the population that is most deprived of physical and financial means to obtain housing. Recent bibliography indicates the contrary. It is assumed, therefore, that the relation between the target public and benefited public diverges from the expected. To this end, data from the National Housing Secretariat (NHS) and the Federal Savings Bank (FSB) were used to provide a detailed explanation of the municipal housing deficit and the projects aimed at solving it according to income and location. In turn, the data include projects that

TAC é doutor em Demografia pela Universidade Estadual de Campinas (UNICAMP), e-mail: tiagoac@ufv.br MSS é doutora em Arquitetura e Urbanismo pelo Instituto de Arquitetura e Urbanismo (IAU-USP), e-mail: siolari@ufv.br 
were approved - but not necessarily executed -until 2013 in the state of São Paulo. These are used as territorial cutting because they present the most significant absolute values of the Union's housing deficit. It is, therefore, evident that the Brazilian housing policy is territorially extensive and correlated with the existence of deficit. The reproduction of inequalities in the access to housing by means of income criteria persists.

Keywords: Housing. Demand. Social inequality. "My House, My Life" Program. São Paulo.

\section{Introdução}

Historicamente, ao menos no caso brasileiro, a questão habitacional foi abordada a partir de espasmos periódicos, com momentos de estabilidade mais ou menos duradouros, condicionada a aspectos macro e microeconômicos.

Parece essencial, pois, abordar, ainda que superficialmente, as características, os desenhos-formatações institucionais, os objetivos e, principalmente, as incongruências inerentes dessas agendas a partir de um levantamento bibliográfico mínimo, compreendendo que o déficit básico de moradias é, em parte, fruto de fissuras inerentes às próprias perspectivas destas agendas.

Autores como Santos (1999) e Bonduki (2008) concordam que a política habitacional brasileira pode ser sintetizada em três grandes períodos: até 1964 (período pré-Banco Nacional de Habitação - BNH), aquele entre 1964 e 1986 (compreendido entre os anos de criação e extinção do BNH) e, por fim, pós-1986 (pós BNH). Decerto, cada um deles apresentava particularidades quanto às metas de cobertura, abrangência e universalização de moradias segundo públicos específicos.

De modo que o sistema responsável pela política habitacional nacional, tal como hoje se encontra, foi um processo de construção (e desconstrução) paulatina de intenções, por vezes desconexas, experienciadas ao longo do último século; o déficit está, em maior ou menor medida, associado a câmbios, inclusive demográficos, vivenciados pela sociedade brasileira e, não menos importante, à dificuldade deste contingente populacional em acessar a política habitacional então vigente e nela permanecer.

A formulação, nesse sentido, de meios de se equalizar as inequidades de aquisição deste bem e ativo, encarando-o como direito, passa pelo Estado. Ao mesmo tempo, o Estado brasileiro lançou mão, em diversos momentos, de estratégias de Mercado.
Essa opção não é fortuita. Estimular o setor imobiliário é aquecer a economia. Seus mecanismos empregam, sobretudo, mão de obra pouco qualificada, dinamizando todo um corolário de campos e atividades econômicas dela dependentes. É tida, portanto, como um "gatilho" de transformações econômicas, mais ou menos intensas, que poderiam ou deveriam garantir diminuição da desigualdade socioeconômica, seja a partir da aquisição de moradia/bem/ativo, ou através da geração de emprego e renda ao edificá-la. Parece ser este um paradigma que ditou e persiste capitaneando a política habitacional nacional.

No entanto, talvez esse seja o primeiro paradoxo que reitera o ciclo vicioso que é incapaz de garantir moradia a todos e, por conseguinte, abrandar desigualdades socioespaciais, hoje, praticamente perenes. Nesse sentido, valer-se de artifícios que promulgam, ainda que indiretamente, especulação imobiliária e concentração/acumulação de riquezas e capital. Reproduz-se, assim, o fenômeno que se planteava mitigar: ratifica-se e reproduzem-se desigualdades sociais e territoriais ao incitar frações do capital, mormente o fundiário, o imobiliário, o da construção civil.

Trata-se, portanto, de um processo bidirecional, retroalimentando-se continuamente, em desigualdades sociais oriundas de um Mercado habitacional especulativo e de políticas públicas de equidade inócuas, acarretando mais defasagem habitacional. E, por fim, déficit aprofundado em desigualdades.

Nesse sentido, as políticas habitacionais jamais foram, de fato, universalizantes no caso brasileiro. Por sujeitarem-se à capacidade de crédito, financiamento, endividamento e, logo, renda. Parece ser este o grande "gargalo" de acesso à moradia e que se encontra no bojo das políticas habitacionais. Camadas inteiras da população brasileira conviveram por gerações à margem do mercado formal de trabalho ou quando se encontravam formalizadas, era de modo precário. Como garantir-lhes habitação se a capacidade destas pessoas de endividamento é mínima? 


\section{Anacronismos estruturais na política habitacional nacional}

Partindo de uma perspectiva histórica, do ponto de vista urbano e arquitetônico, aliada à dinâmica demográfica, o ínterim até 1964 se notabiliza por soluções habitacionais pontuais. Encabeçadas pelos Institutos de Aposentadoria e Previdência (IAP). Com efeito, a preocupação jamais residiu na universalização da habitação, posto que esta se tratasse de solução corporativista. 0 requisito básico para atingi-la residia no pertencimento a uma categoria trabalhista ${ }^{1}$ industriários, comerciários, ferroviários, etc. Era, em suma, uma solução desarticulada e pontual (Negrelos, 2014).

É preciso não perder de vista que foi ao longo desse período que o processo de industrialização se intensificou e, concomitantemente, o de urbanização. Além dos processos de redistribuição e concentração populacional condicionada pelos também processos de acumulação espacial do capital e, logo, dos meios de produção. Destaca-se o próprio crescimento absoluto da população brasileira. E, por fim, o derradeiro fruto da alteração do regime produtivo, mercantil para industrial, foi uma divisão social do trabalho excludente, ao menos no caso latino-americano (Maricato, 2003; Negrelos, 2014).

Convém lembrar que, neste período, houve a primeira iniciativa estatal para produção habitacional, a Fundação da Casa Popular (FCP). Criada em 1946 (pela Lei Federal no 9.218, Brasil, 1946), é tida como a precursora do Banco Nacional de Habitação (BNH).

De qualquer forma, há duas contribuições importantes para as discussões que sucederam à sua extinção: 1) a difusão do modelo da "casa própria"; 2) a preconização de medidas operacionais visando à ampliação do programa para parte considerável da população de baixa renda (Manoel, 2004; Azevedo \& Andrade, 2007).

Enquanto o período gênese da política habitacional nacional se caracterizava por soluções atomizadas e desarticuladas, o período subsequente é notabilizado pela antítese, a centralização, reflexo, inclusive, do regime ditatorial de então.

Não menos importante foi o fato de, talvez, pela primeira vez, a questão habitacional ser vista como um

\footnotetext{
${ }^{1}$ Embora o Plano C objetivasse mutuários externos de acordo com a conveniência, objetivando ganhos constantes e elevados.
}

mercado em potencial. A problemática habitacional é atacada em três frentes: a) garantindo emprego e renda para uma população pouco qualificada responsável por edificar as novas moradias, b) dinamizando setores da indústria da construção civil (cimentícia, mineradora, siderurgia, etc.) e c) embora indiretamente, aquecendo o setor financeiro ao alavancar o crédito. Todos estes aspectos foram decisivos para o incremento da capacidade da poupança de longo prazo. Sendo tal capacidade encarada como o alicerce do sistema.

O sistema [pré 64] de concessão de empréstimos a valores nominais fixos distorcia o mercado em três aspectos: primeiro, premiava os mutuários, os quais pagavam suas amortizações em cruzeiros desvalorizados; segundo, afastava a poupança voluntária desse mercado, tendo em vista as taxas reais de juros fortemente negativas; terceiro, minguava a capacidade de aplicação das poucas instituições existentes. (Kampel \& Valle, 1974, p. 13).

Todavia, a resposta à incapacidade de articulação entre captação, gerenciamento e rentabilidade dos recursos só reiterou a marginalidade, a exclusão e a segregação. Apartou estratos da população brasileira que estavam, da mesma forma, à margem do mercado formal de trabalho ou que, no mínimo, conseguissem assegurar a capacidade de pagamento da dívida assumida. A rentabilidade (amparada por juros ajustáveis) e a segurança de retorno do investimento tornaram-se pilares do sistema. Não é casual, portanto, que boa parte da produção habitacional do período se destinou à classe média.

Enquanto a política pré-1964 renegava contingentes expressivos devido a sua desconexão sistêmica e estrutural, a exclusão persistiu pós-1964 segundo critérios de renda.

A situação habitacional se deteriora ainda mais a partir das mudanças estruturais, que preconizavam o Estado Mínimo. Neste contexto, políticas públicas foram seriamente afetadas. A habitacional não foi exceção. Seu fruto mais evidente foi o fechamento do Banco Nacional de Habitação em 1986, o que significou a supressão de qualquer agenda sobre o assunto.

[...] recessão, inflação, desemprego e queda dos níveis salariais. Este processo teve enorme repercussão no Sistema Financeiro da Habitação (SFH), com a redução da sua capacidade de investimento, devido à retração dos saldos 
do FGTS e da poupança e forte aumento na inadimplência, gerado por um cada vez maior descompasso entre o aumento das prestações e a capacidade de pagamento dos mutuários. (Bonduki, 2008, p. 75).

A partir daí uma política habitacional de fato integrada e de abrangência nacional inexiste por, pelo menos, uma década e meia. Contudo, a demanda por moradias se manteve, quando não, se acentuou. A população brasileira atingia, em 1991, 146.917 .459 habitantes, com um grau de urbanização de 75,89\%, ou seja, cada vez mais urbana e geograficamente concentrada.

Neste ínterim, vale destacar a elaboração e aprovação da nova Constituição Brasileira (Brasil, 1988), trazendo direitos e garantias fundamentais. Ainda assim, a moradia como Direito Social apenas foi incorporada com a Emenda Constitucional de 14 de fevereiro de 2000.

De acordo com Santos (1999), a questão habitacional é verdadeiramente retomada somente em $1998^{2}$, mas ainda de modo incipiente. Ainda que houvesse instrumentos voltados às camadas mais populares, estes instrumentos eram inócuos diante do déficit e da demanda acumulados desde o início do século XX. Os recursos destinavam-se a financiar, prioritariamente, empreendimentos cuja rentabilidade e retorno eram confiáveis, garantidos e seguros (Vasconcelos \& Cândido, 1996). Em síntese, houve avanços, mas o prisma e os preceitos estabelecidos ao longo do período 1964-1986 mantinham-se, em essência, firmemente inalterados (Cardoso, 2006; Klintowitz, 2011; Pugh, 1991, 1994; Sánchez, 2013).

Outra conquista foi a aprovação da Lei Federal no 10.257 de 2001, já que ela dispõe de uma série de instrumentos que viabilizariam o cumprimento da função social da propriedade. Em resumo, possibilitaria a aquisição de terras urbanas ou a criação de Zonas Especiais de Interesse Social (ZEIS) para fins de moradia, principalmente, a de cunho social, atacando um dos fatores que influenciam o preço final da unidade: o solo urbano. No entanto, os propósitos esbarram em localismos (Brandão, 2007), haja vista que a aplicação da lei depende, fundamentalmente,

\footnotetext{
${ }^{2}$ Embora, no Estado de São Paulo, desde 1990, parte dos recursos do ICMS seja destinada à produção habitacional desenvolvida pela Companhia de Desenvolvimento Habitacional e Urbano (CDHU).
}

da vontade do poder público municipal. Em síntese, o grande obstáculo é político, uma vez que, geralmente, os responsáveis pela aprovação e efetividade da lei são, da mesma forma, os detentores dos bens urbanos alvos das políticas antiespeculação (Maricato, 2009).

Por fim, outro triunfo foi a aprovação, em 2005, do Fundo Nacional de Habitação de Interesse Social (FNHIS) e do Sistema Nacional de Habitação de Interesse Social (SNHIS). Talvez, os principais instrumentos para a população mais carente e que, reconhecidamente, não é atingida pelas linhas de crédito usuais, inclusive por se tratar de um estrato com sérios empecilhos à formalização trabalhista, a comprovação de rendimentos, a capacidade de endividamento, etc. Vale lembrar que o FNHIS deriva de projeto de lei de iniciativa popular apresentado em 1991. Logo, percebe-se pela própria forma de encaminhamento do FNHIS que a participação popular era incentivada desde o início e que estava articulada com outros instrumentos da política habitacional. Por exemplo, o processo participativo foi uma vez mais enaltecido na arquitetura do próprio Plano Nacional de Habitação (PlanHab), uma vez que ele contou "[...] com o conjunto de segmentos que compõem o Conselho das Cidades, desde sua [Conselho das Cidades] criação em 2003" (Amore et al., 2015).

Ademais, ainda segundo Amore et al. (2015), SNHIS/FNHIS previam o concatenamento de fundos dos diferentes entes federativos, todos controlados socialmente por conselhos populares e orquestrados pelos Planos Locais de Habitação de Interesse Social (PLHIS). Todos os municípios que quisessem participar do sistema e, assim, terem acesso aos fundos, deveriam compulsoriamente se comprometer a elaborar seus PLHIS, enfatizando a participação e o controle social.

Outra preocupação era assegurar que os PLHIS não fossem desconectados das questões fundiárias locais, dada a heterogeneidade do padrão de ocupação urbano e as realidades nacionais. Logo, estes planos deveriam suceder os Planos Diretores Participativos, apresentando estratégias fundiárias para a questão habitacional (Amore et al., 2015).

Porém, a limitação estrutural do fundo é que ele é composto, basicamente, por recursos não onerosos provenientes do Orçamento Geral da União (OGU). Os repasses podem ser, portanto, instáveis - ora substanciais, ora insignificantes - dependendo das circunstâncias e da visão de Estado em vigência, afetando os objetivos traçados previamente. Enfim, definitivamente não é 
uma mudança substancial a ponto de sanar os valores absolutos do déficit habitacional básico (Valença \& Bonates, 2010).

0 surgimento do Programa Minha Casa, Minha Vida é posterior à discussão e à formulação do SNHIS, do FNHIS e do PlanHab. Em realidade, como bem alerta Balbim et al. (2013), o PMCMV não tem o caráter de política, mas de instrumento de uma visão mais abrangente, ou seja, da política definida no PlanHab. Porém, o PMCMV acaba eclipsando toda a variedade de soluções presentes no PlanHab.

0 programa nasce como resposta à crise econômica de 2008 e do enfraquecimento do próprio Ministério das Cidades que, à época, encabeçava juntamente com movimentos de luta pela moradia a Campanha Nacional pela Moradia Digna (Fix, 2011). Tal campanha pregava a vinculação entre os investimentos em habitação e PIB de forma a alimentar os Fundos de Habitação de Interesse Social. Esperava-se, dessa maneira, interromper um problema estrutural do sistema de financiamento de habitações de interesse social. Esta abordagem, contudo, não vingou.

De qualquer forma, o PMCMV surgiu como estratégia de incentivo econômico de caráter anticíclico. Logo, não é casual que parte considerável dos fundos é de origem onerosa (sobretudo, FGTS), garantindo - ainda que com riscos de mercado - lucros mediante juros. Enfim, assegurando lucros também ao setor financeiro e não somente ao produtivo (Ferreira, 2012). O PMCMV atingiu tal importância econômica que, em 2011, em sua segunda fase, passa a figurar no Programa de Aceleração do Crescimento (PAC). Seu produto final era a construção de novas unidades habitacionais. Em resumo, parece que a abordagem econômica, produtivista e financeira da moradia explica sua hegemonia no espectro de soluções habitacionais promovidas pelo PlanHab (Amore et al., 2015; Balbim et al., 2013).

\section{O Programa Minha Casa, Minha Vida}

O programa foi criado mediante a Medida Provisória no 459, de 25 de março de 2009 e regulamentado pelo Decreto no 6.819, de 13 de abril de 2009 (Brasil, 2009a, 2009b). Em julho do mesmo ano, o Decreto foi convertido em lei nacional, a Lei no 11.977/2009 (Brasil, 2009c). Embora outros programas habitacionais tivessem sido elaborados e aplicados em todo o território nacional, o PMCMV é o primeiro após Constituição de 1988 com tamanha relevância e abrangência.

0 atendimento do Programa é categorizado em virtude da renda e o fundo de financiamento. Trata-se de três categorias: o financiamento com participação do Fundo de Desenvolvimento Social (FDS) e do Fundo de Arrendamento Residencial (FAR), atendendo a famílias organizadas em cooperativas habitacionais ou mistas, associações, demais entidades privadas sem fins lucrativos e famílias com renda inferior a $\mathrm{R} \$ 1.395,00$ visando à produção, aquisição e requalificação de imóveis urbanos, denominado Faixa 1; financiamento com o FAR e com o Fundo de Garantia do Tempo de Serviço (FGTS), com renda entre R $\$ 1.395,01$ e $\mathrm{R} \$ 2.790,00$, denominado Faixa 2; e financiamento com recursos exclusivos do FGTS, com renda entre $\mathrm{R} \$ 2.790,01$ e R\$4.650,00, denominado Faixa 3.

Tais valores estão descritos na Lei e compõem a primeira fase do PMCMV com vigência nos anos 2009-2011. A segunda fase do PMCMV teve vigência entre os anos 2011 e 2014 e foram apresentados novos valores limítrofes de composição das faixas do Programa: Faixa 1- até R $\$ 1.600,00 ;$ Faixa 2 - R $\$ 1.600,01$ a R\$3.100,00; e, por fim, a Faixa 3 - R\$ 3.100,01 a $\mathrm{R} \$ 5.000,00$. A partir de 2012 foi acrescentada outra variação de limite de renda em virtude da localização do imóvel e do beneficiário. Regiões metropolitanas teriam a elevação dos limites apenas para a Faixa 3. A categoria Faixa 1 é a parte do Programa destinada para atendimento à moradia de interesse social, podendo, em situações descritas na lei, desobrigar a participação financeira dos beneficiários, sob forma de prestação.

Na Tabela 1, são apresentadas algumas particularidades do programa segundo a fonte do recurso financeiro em questão.

As faixas do Programa não são indexadas segundo o salário mínimo. Desta forma, em 2009 quando foi instituído o PMCMV, o valor limítrofe para o enquadramento da Faixa 1 coincidia com o valor de três salários mínimos vigentes à época. No decorrer dos anos, com os reajustes salariais, esta equivalência não perdurou, defasando-se.

Em 2015, teve início a terceira fase, e o PMCMV apresentou novos valores limítrofes e acrescentou uma nova faixa de categorização, com previsão de vigência para os anos 2015 a 2018: Faixa 1- até $\mathrm{R} \$ 1.800,00$; Faixa 1,5 - R\$ 1.800,01 a R\$2.350,00; Faixa 2 - R\$2.350,01 a R\$3.600,00; e, por fim, a Faixa 3 - R\$3.600,01 a R\$6.500,00. 


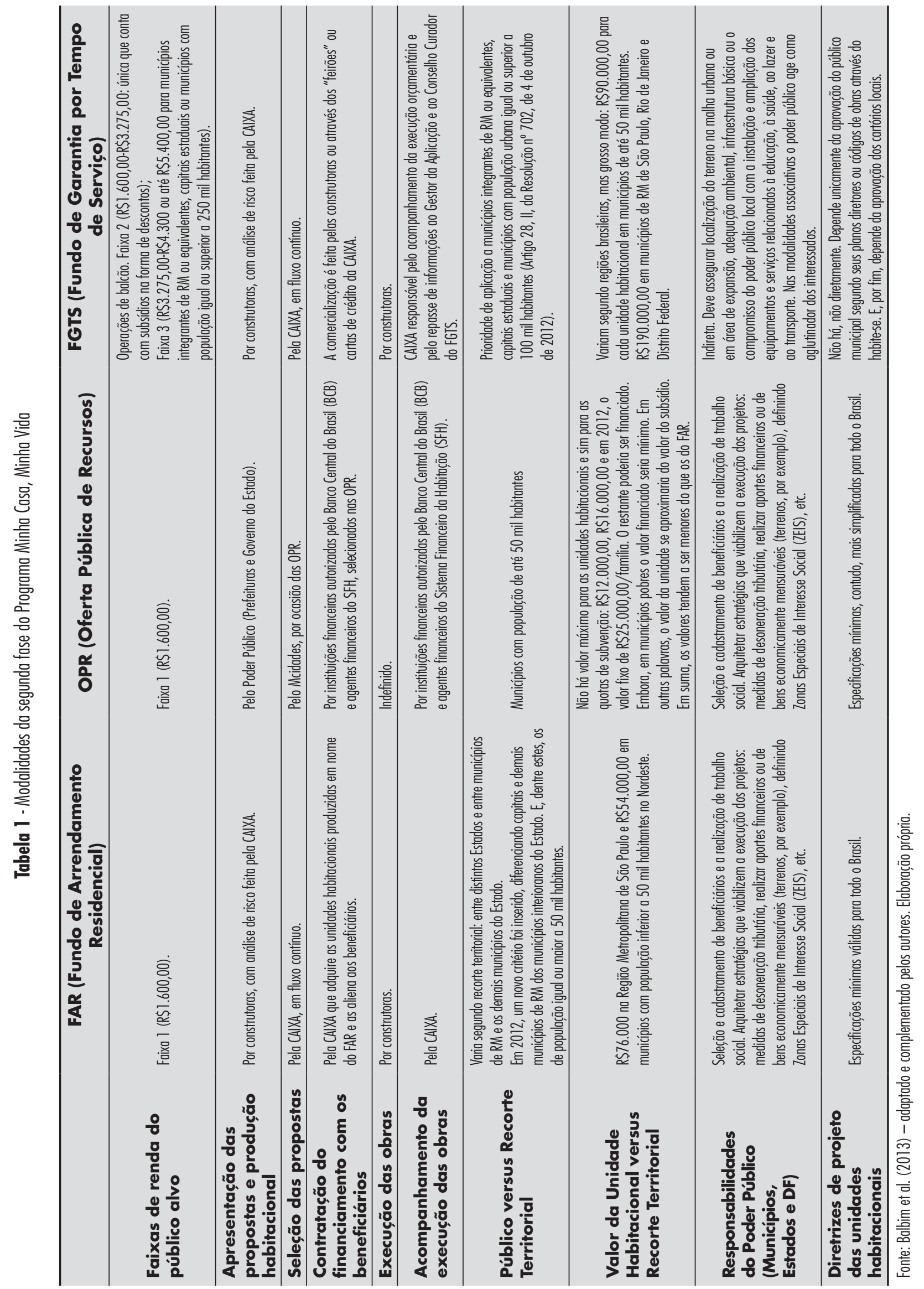




\section{Metodologia}

Haja vista que o principal intuito do presente artigo é esclarecer o possível desequilíbrio entre principais demandantes por habitação e público de fato atingido pelo programa, a presente investigação se vale de duas principais fontes de dados.

A primeira retrata o déficit habitacional em 2000 e 2010, com dados provenientes da Fundação João Pinheiro (FJP-MG), em que se mapeia o déficit habitacional total e básico, caracterizando-os por renda e também por seus diversos componentes: reposição do estoque (depreciação do imóvel e domicílios rústicos) e déficit por incremento do estoque (domicílios improvisados, coabitação familiar e ônus excessivo com aluguel).

Além disso, a base permite desagregações por faixas de renda (para algumas variáveis), por situação de domicílio (também para algumas variáveis) e territoriais (municípios com 200.000 habitantes ou mais, mas, sobretudo, até o recorte mínimo das microrregiões estaduais).

Por fim, a fonte secundária em questão garimpa seus dados em outras fontes secundárias: a Pesquisa Nacional por Amostra de Domicílios (PNAD), bem como os microdados dos Censos Demográficos 2000 e 2010.

Asegunda, por sua vez, refere-se aos empreendimentos ${ }^{3}$ construídos ou, no mínimo, contratados para o Estado de São Paulo até 2013. Tais dados foram obtidos junto à Secretaria Nacional de Habitação (SNH) do Ministério das Cidades (MC). A base foi, em realidade, alimentada pela Caixa Econômica Federal (CEF), principal operadora financeira do sistema.

Como será visto mais à frente, elege-se o Estado de São Paulo como recorte territorial, por ser neste estado que se pode evidenciar a concentração dos maiores valores absolutos do déficit habitacional. Ademais, espera-se compreender minimamente se o Estado mais rico da Federação está realmente focalizando o público mais carente, até mesmo como forma de diminuir desigualdades socioeconômicas ao garantir-lhe moradia.

Opta-se, ao menos nesse momento inicial da investigação, por se utilizar os dados de 2000 e 2010, uma vez que estão disponíveis on-line.

\footnotetext{
${ }^{3}$ No entanto, também apresenta valores de déficit habitacional segundo municípios. Valores estes muito próximos aos apresentados pela FJP. Em realidade, os valores do déficit da SNH derivam da própria FJP.
}

Para fins comparativos, opta-se por se utilizar a definição de déficit habitacional básico.

0 cálculo do déficit habitacional para municípios, em decorrência dos fatores explicitados nos capítulos anteriores, atém-se ao somatório dos domicílios rústicos, dos improvisados e da coabitação familiar e recebe a denominação de déficit habitacional básico. (FJP, 2001).

Assim, são excluídos componentes do tipo "ônus excessivo com aluguel" e "déficit por depreciação", uma vez que "[...] na inadequação, um domicílio pode figurar diversas vezes; nesse caso, o domicílio não deve ser reposto, mas sim adequado, e segundo cada critério no qual se encaixa" (FJP, 2011).

\section{Resultados e discussão}

\section{Cenário das últimas décadas}

Embora, mais recentemente tenha ocorrido um reavivamento da política habitacional, tanto em termos conceituais como econômicos, com a injeção de grandes somas de recursos financeiros, frutos de um cenário macroeconômico favorável, a questão do déficit básico perdura.

Os dados da Tabela 2 esclarecem a magnitude do problema e seu agravamento ao longo da década 2000-2010.

Percebe-se que, embora o déficit básico relativo de moradias brasileiras tenha diminuído ao longo da década (passando de 13,2\% para 12,1\% dos domicílios permanentes), o mesmo não ocorre em valores absolutos.

Nesse caso, nota-se um aumento de algo como 1 milhão de unidades habitacionais. Um valor desmedido para um déficit já gigantesco.

Os dados permitem depreender, ademais, alterações na localização do déficit (Gráfico 1).

Constata-se um abrandamento do déficit na Região Nordeste, enquanto seu acirramento na Região Sudeste ao longo do período (Gráficos 2 e 3).

Nesse sentido, os gráficos permitem constatar a agudeza do fenômeno, fosse em escala nacional, regional ou estadual, dado o incremento dos valores absolutos. Em suma, estes valores demonstram que se trata de algo crônico, sintomático e universal, posto 


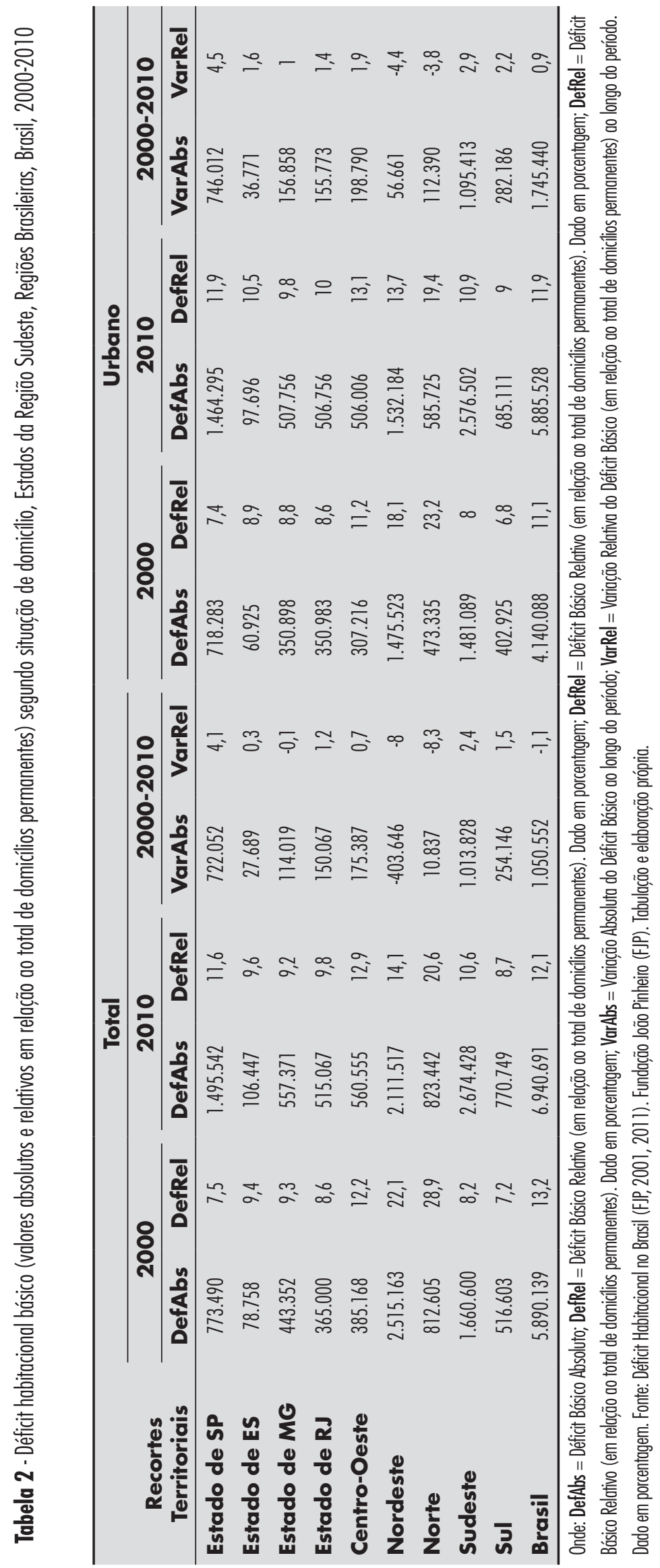




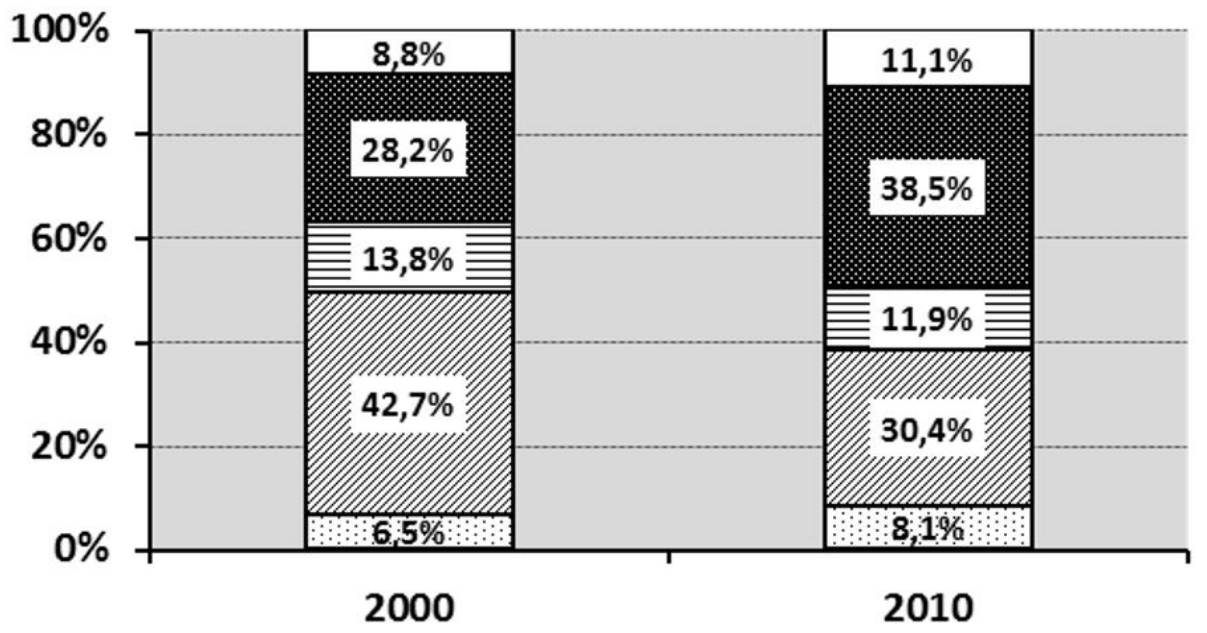

$\square$ Sul

앙 Sudeste

目 Norte

Nordeste

Centro-Oeste

Gráfico 1 - Déficit habitacional básico brasileiro segundo Regiões Brasileiras, Brasil, 2000-2010

Fonte: Déficit Habitacional no Brasil (FJP, 2001, 2011. Fundaç̃o Joõo Pinheiro (FJP). Tabulacãao e elaboraccão própria.

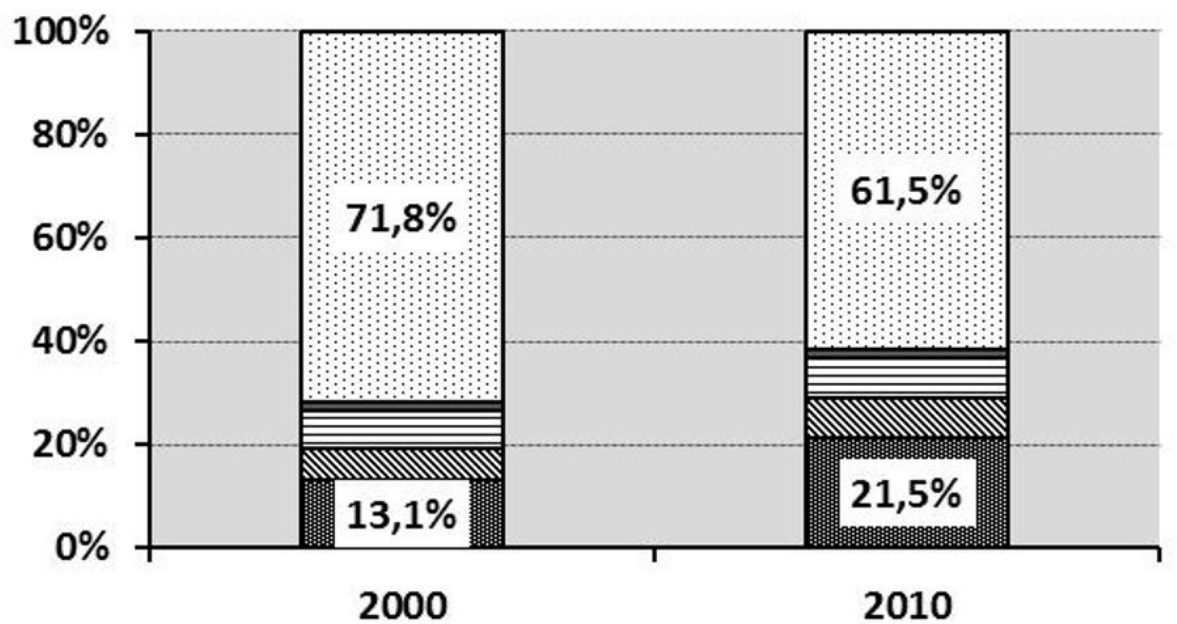

밀

Estado de ES

目Estado de MG

$\mathbb{N}$ Estado de RJ

Estado de SP

Gráfico 2 - Déficit habitacional básico segundo Estados, Brasil, 2010

Fonte: Déficit Habitacional no Brasil (FJP, 2001, 2011). Fundação João Pinheiro (FJP). Tabulação e elaboraccão própria.

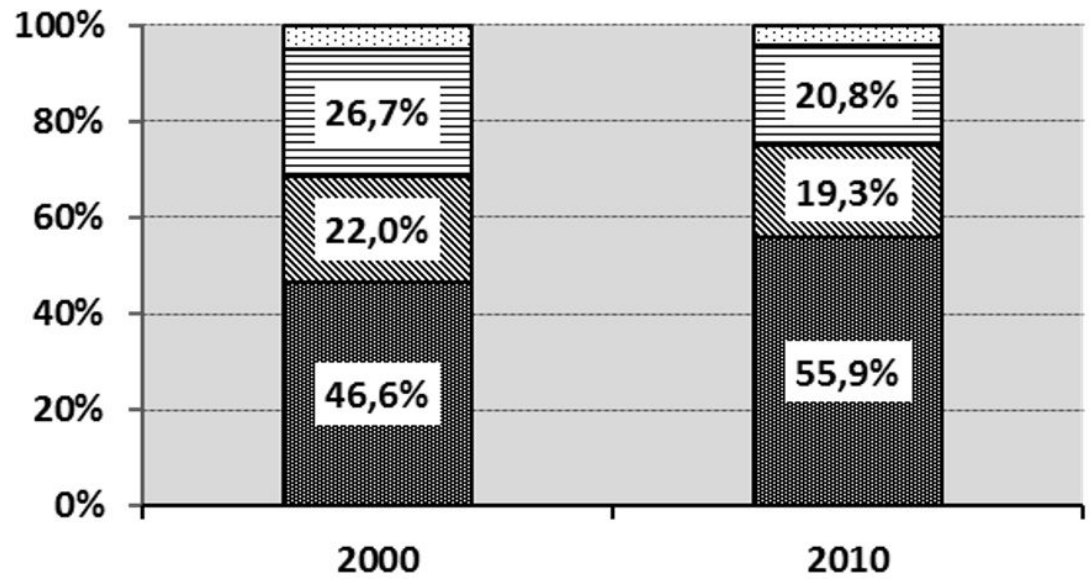

TEstado de ES

目Estado de MG

$\mathbb{\mathbb { Q }}$ Estado de RJ

Estado de SP

Gráfico 3 - Déficit habitacional básico segundo Estados, Região Sudeste, 2010

Fonte: Déficit Habitacional no Brasil (FJP, 2001, 2011). Fundação João Pinheiro (FJP). Tabulacão e elaboracão própria. 
que se mantém ao longo do tempo independentemente do recorte territorial.

Os dados, inclusive, justificam a escolha do Estado de São Paulo como estudo de caso. Tais dados são inequívocos ao demonstrarem que o déficit aí se acentua, correspondendo a valores absolutos colossais. Não por acaso, boa parte dos investimentos do "Programa Minha Casa, Minha Vida" (PMCMV) lhe são destinados.

Ademais, proporcionam uma derradeira leitura. 0 déficit básico de moradias e seu crescimento são fenômenos proeminentemente urbanos (como era de se esperar dado o elevado grau de urbanização nacional). Afinal, concentram-se em regiões eminentemente urbanas (Figuras 1 e 2), fossem estas metropolitanas ou centros emergentes interioranos. Ilustram dívidas e passivos urbanos gerados em um momento de inflexão da sociedade brasileira. A opção pelo latifúndio, pela não reforma agrária, pelo êxodo rural em direção às cidades, etc., de um processo de desenvolvimento econômico e industrial horizontal, extensivo, excludente e desigual. Pautado na exploração da mão de obra e, consequente, marginalidade de

\section{3}

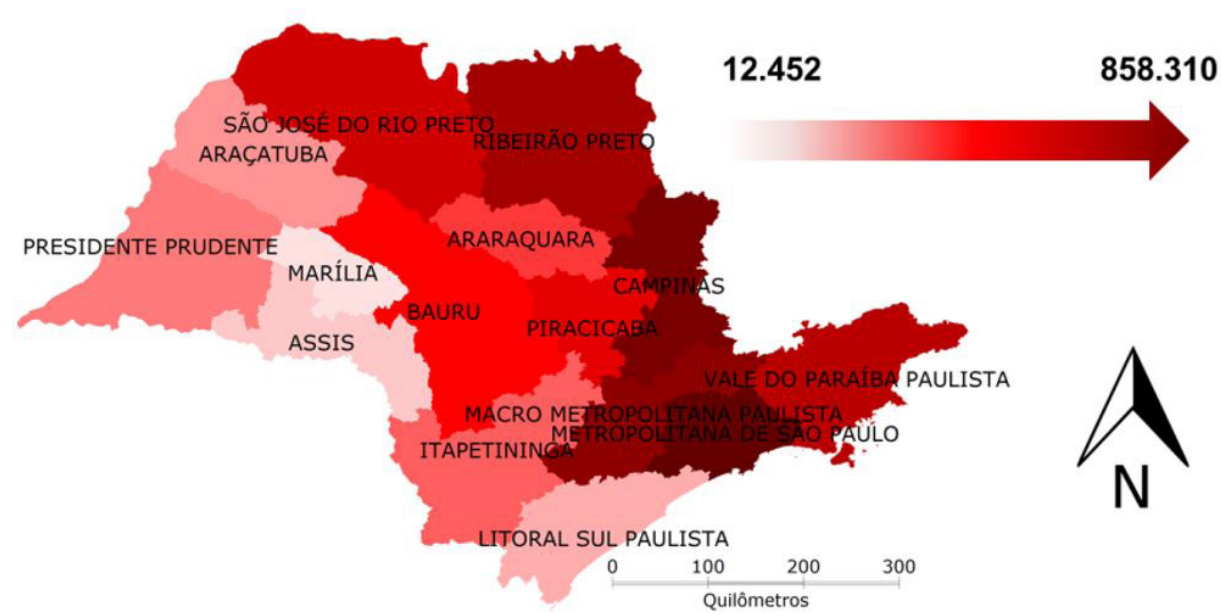

Figura 1 - Déficit habitacional básico total (valores absolutos) segundo mesorregiões paulistas, Estado de São Paulo, 2013 Fonte: IBGE (2005) (LatLong. Datum:SAD69). Escala 1:2.500.000. Elaboração própria.

\section{3}

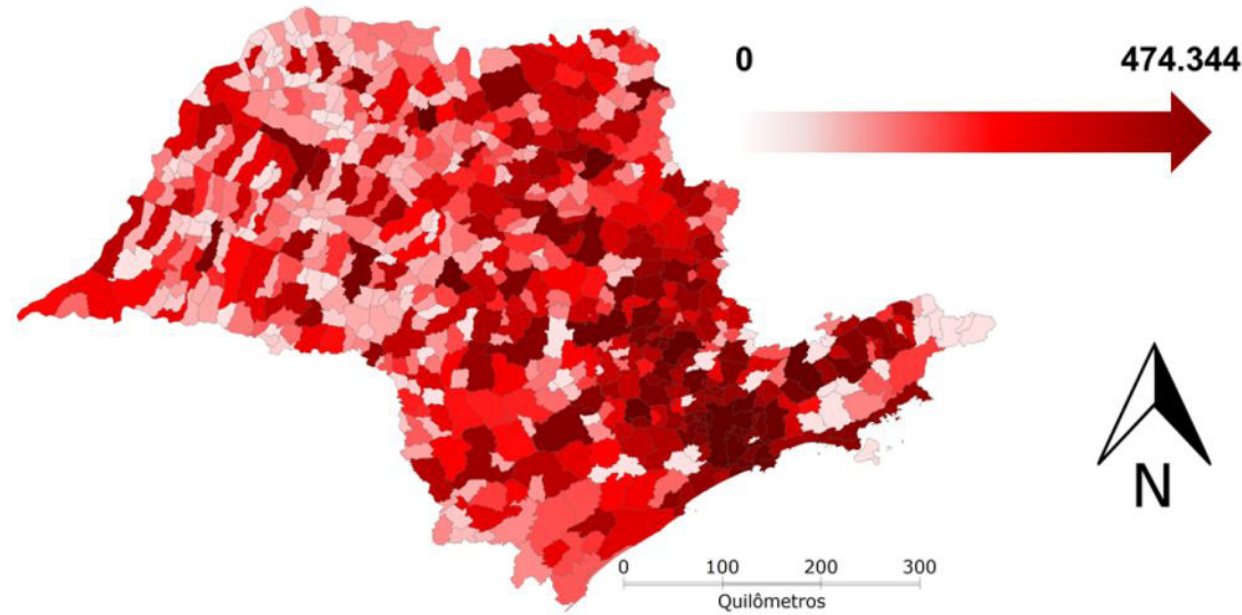

Figura 2 - Déficit habitacional básico total (valores absolutos) segundo municípios paulistas, Estado de São Paulo, 2013 Fonte: IBGE (2005) (LatLong. Datum:SAD69). Escala 1:2.500.000. Elaboracão própria. 
estratos populacionais, que sem alternativas se veem obrigados a morar mal (ocupações, favelas, mananciais, loteamentos clandestinos, irregulares, cortiços, coabitações forçadas, aluguéis extorsivos, etc.) ou, em última instância, a não residir de forma alguma (Rolnik \& Klink, 2011).

A população inicialmente expulsa do campo - por vezes, pela não reforma agrária - encontrou outra barreira no seu destino: outra variedade de não reforma fundiária, agora, urbana. Em outras palavras, pela também concentração e controle de terras, imóveis e recursos nas mãos de poucos. 0 conceito basilar desta forma de exploração reside no direito de propriedade precedendo o direito de posse/uso (Balbim et al., 2015; Georges et al., 2014).

Parece importante frisar, assim como minimamente elucidado - embora de modo visual por meio da Figura 2 - que, mais recentemente, o déficit não é uma particularidade das grandes regiões metropolitanas paulistas. Diversas cidades intermédias do interior apresentam valores absolutos de déficit habitacional básico dignos de nota. 0 índice de Moran Global ajuda a confirmar esta suposição inicial, posto que apresenta baixa correlação espacial positiva $0,12 \mathrm{com}$ grande significância estatística 0,01. Em resumo, o déficit está espacialmente desconcentrado, indicando que problemas urbanos anteriormente típicos das grandes aglomerações metropolitanas começam a se manifestar no interior, principalmente, em cidades intermédias do interior paulista.
Entretanto, tratar dos valores totais de déficit de moradias não propicia a real dimensão daqueles que mais carecem dela (Gráfico 4).

Torna-se evidente, portanto, que há um perfil muito bem delineado de estrato populacional que mais necessita de habitação: indivíduos e famílias, cujo rendimento atinge no máximo três salários mínimos. Esse conjunto representa quase $70 \%$ do total do déficit habitacional básico nacional.

Inferindo que há uma correlação entre três distintas dimensões: população, território e déficit, nota-se a partir dos dados uma concentração do déficit segundo renda, novamente, nas Regiões Sudeste e Nordeste (Gráfico 5).

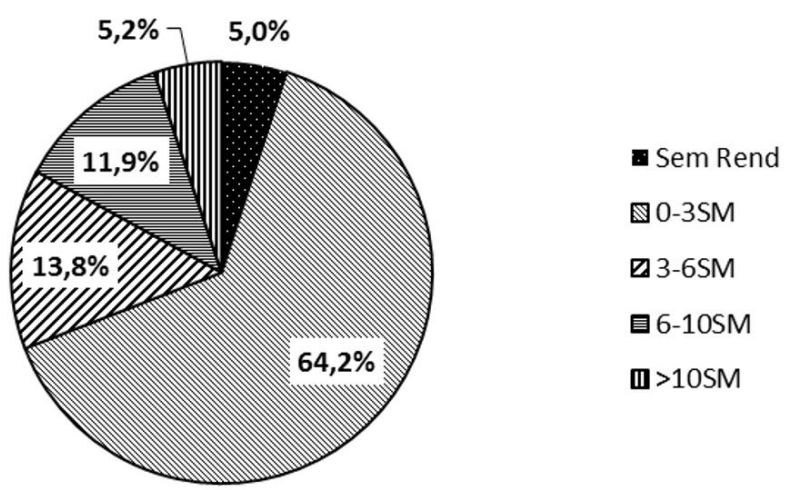

Gráfico 4 - Déficit habitacional básico segundo faixas de renda, Brasil, 2010 Fonte: Déficit Habitacional no Brasil (FJP, 2001, 2011). Fundaç̃o Jõ̃o Pinheiro (FJP). Tabulação e elaboração própria.

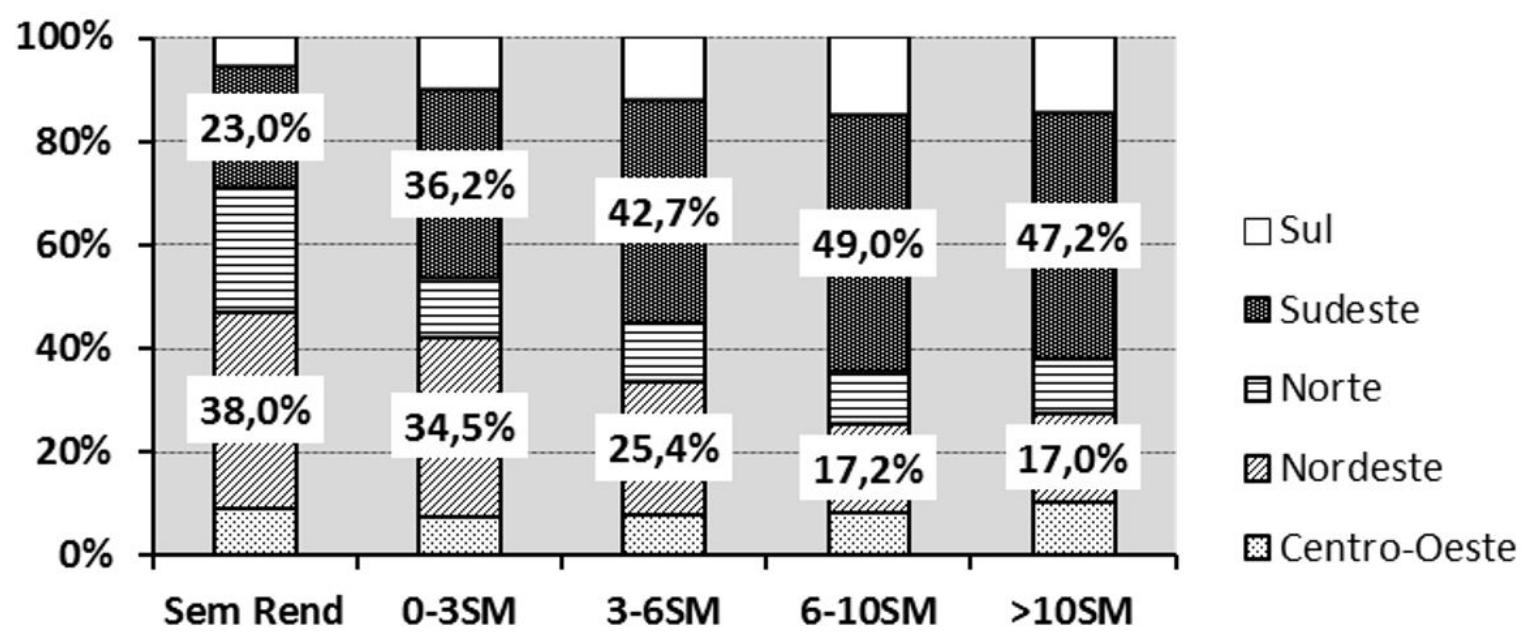

Gráfico 5 - Déficit habitacional básico segundo faixas de renda domiciliar, Regiões Brasileiras, Brasil, 2010 Fonte: Déficit Habitacional no Brasil (FJP, 2001, 2011). Fundacão João Pinheiro (FJP). Tabulaç̃ão e elaboracãão própria. 
Recordando-se que o Estado de São Paulo apresenta valores absolutos expressivos de déficit, não é arbitrário que tal Estado abarque boa parte da população carente demandante de habitação (Gráficos 6 e 7).

Dado os valores absolutos do déficit básico de moradias paulista, o Estado de São Paulo sozinho representa $18,5 \%$ dos casos brasileiros de déficit até três salários mínimos.

Por fim, esmiunçando-se o caso paulista, constata-se ali que quase $60 \%$ (59,5\%) da população de até três salários mínimos compõe o déficit básico de moradias estaduais (Gráfico 8). Uma fração digna de nota, embora ligeiramente menor comparativamente à participação da mesma camada nos demais Estados investigados (ES, MG e RJ).

Em suma, o caso paulista é interessante de ser problematizado. Tendo-se em vista que se trata do Estado mais rico da Federação, seu déficit e o perfil da população componente dele, não é exagero dizer que é um Estado extremamente desigual. Impossibilita a aquisição de novas moradias por muitos, sobretudo, pelos mais carentes. Provavelmente, o preço da terra e da construção em si se apresentam decisivos e coercitivos a ponto de afetar diretamente o déficit habitacional básico. Talvez ali, os preceitos equalizadores

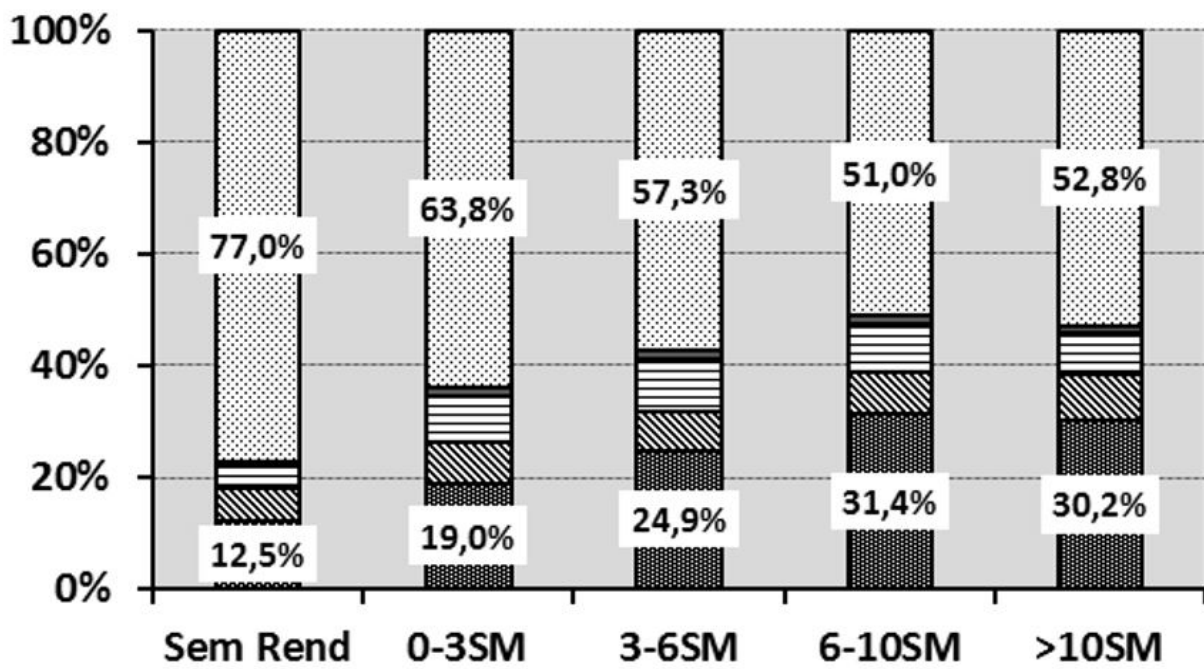

Gráfico 6 - Déficit habitacional básico segundo faixas de renda domiciliar, Estados do Sudeste, Brasil, 2010 Fonte: Déficit Habitacional no Brasil (FJP, 2001, 2011). Fundação João Pinheiro (FJP). Tabulação e elaboração própria.

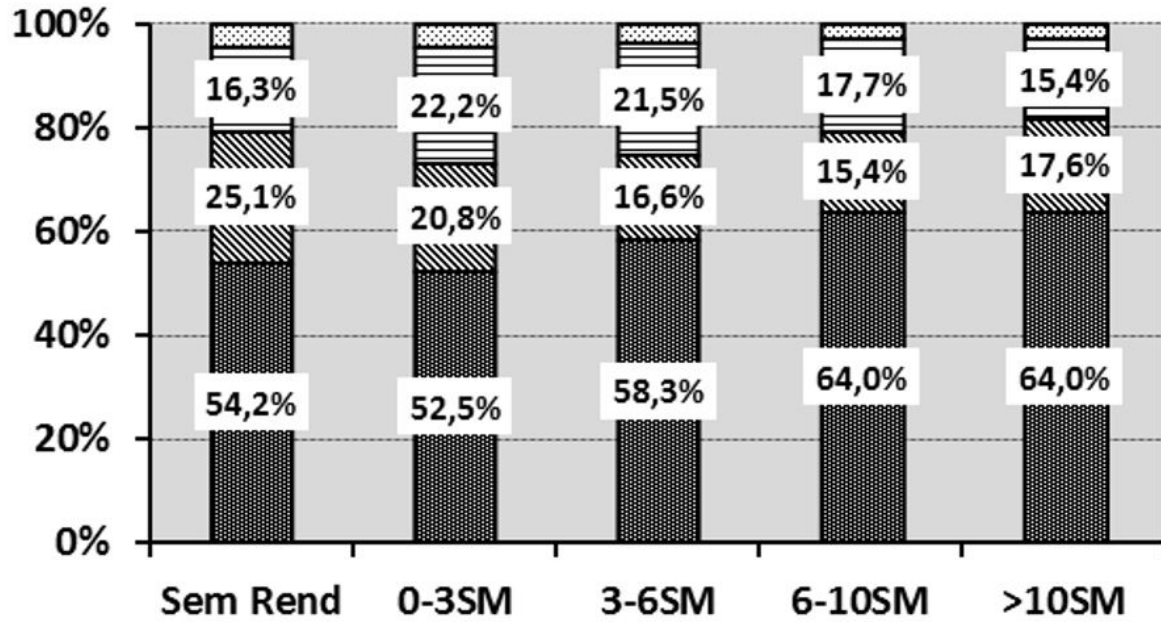

Demais

Estado de ES 日Estado de MG $\mathbb{B}$ Estado de RJ

Estado de SP
웅 Estado de ES

目Estado de MG

$\mathbb{Q}$ Estado de RJ

Estado de SP

Gráfico 7 - Déficit habitacional básico segundo faixas de renda domiciliar, Sudeste, 2010

Fonte: Déficit Habitacional no Brasil (FJP, 2001, 2011). Fundacão João Pinheiro (FJP). Tabulaccão e elaboração própria. 


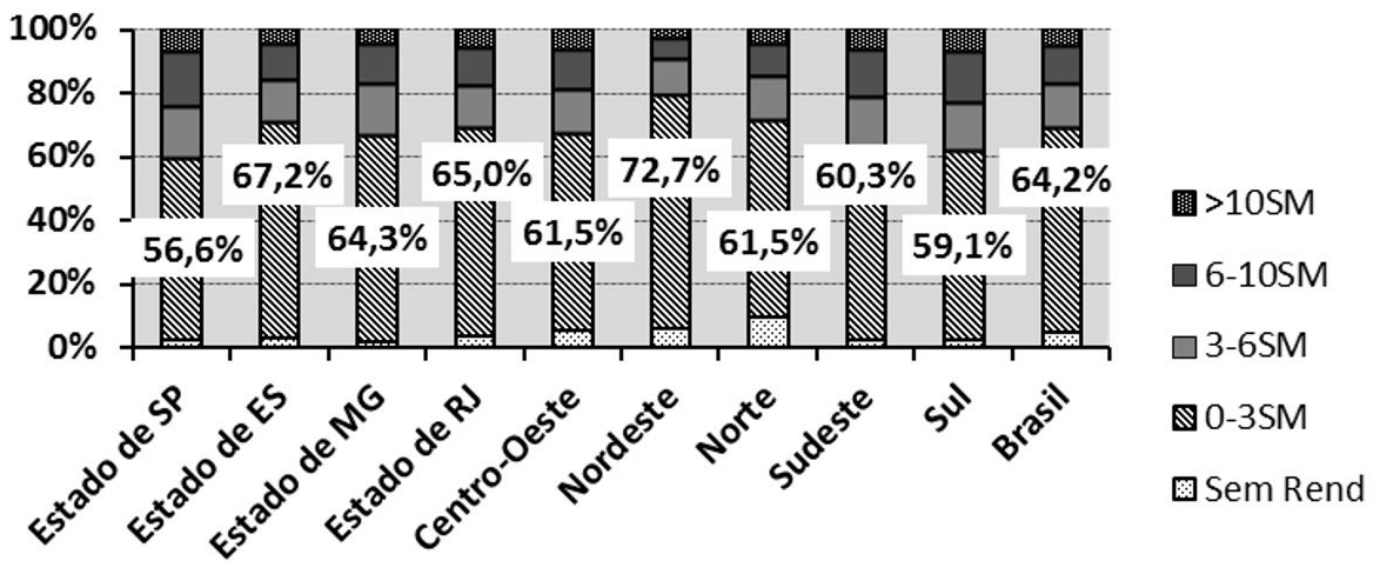

Gráfico 8 - Déficit habitacional básico segundo faixas de renda domiciliar, Estados, Regiões Brasileiras, Brasil, 2010 Fonte: Déficit Habitacional no Brasil (FJP, 2001, 2011). Fundação João Pinheiro (FJP). Tabulacạ̃o e elaboracạ̃o própria.

do Estatuto das Cidades se façam mais urgentes e necessários.

As causas não são fortuitas. Aliada à enorme desigualdade regional e social, a priorização pelo retorno financeiro, objetivando a capitalização a juros elevados, torna a formatação do Sistema Nacional de Habitação - excluindo os fundos de habitação de interesse social - um limitador a priori.

Parte do problema, como discutido em seções anteriores, foi sanado com a criação do SNHIS (Sistema Nacional de Habitação de Interesse Social). Contudo, é inegável que, dado o passivo constantemente gerado e acumulado, ao longo de décadas, de políticas e objetivos habitacionais infelizes e ineficazes, muito ainda está por ser feito.

Infelizmente, os dados disponibilizados pela Fundação João Pinheiro não permitem esclarecer o déficit habitacional básico, segundo classes de renda para o ano de 2000. No entanto, como visto, possibilitam esse mesmo tipo de análise para 2010.

\section{Indícios de desarmonia}

Segundo dados da Secretaria Nacional de Habitação (SNH) do Ministério das Cidades (MC) e da Caixa Econômica Federal (CEF), 606.093 unidades habitacionais foram contratadas pelos Programas Minha Casa, Minha Vida I e II para o Estado de São Paulo até o ano de 2013. Desse total, 603.733 destinavam-se a abrandar o déficit urbano e, somente, 2.360 o rural.

Decerto, como comentado anteriormente, a problemática habitacional se concentra, espacialmente, sobretudo, no ambiente urbano devido ao processo histórico de formação das aglomerações brasileiras pautada pela acumulação e concentração dos meios de produção e, consequentemente, da força de trabalho. Contudo, a inversão de recursos, nesse caso, é totalmente assimétrica-desmedida.

Os empreendimentos contratados para zonas rurais não passam de $0,4 \%$ do total de empreendimentos contratados para o Estado de São Paulo em 2013. Da mesma forma, essas 2.360 unidades não passam de 7,6\% do total do déficit habitacional básico paulista rural em 2010.

A desatenção dada à questão habitacional rural parece ser mais uma das causas da não fixação dessas populações nestas áreas, contribuindo para novos fluxos migratórios rurais-urbanos (embora muito mais incipientes que os de décadas passadas).

Regressando à discussão sobre o déficit total e focalizando, posteriormente, o déficit urbano, as 606.093 unidades contratadas equivalem a $40,5 \%$ do déficit habitacional básico paulista em 2010. A porcentagem é ligeiramente maior, quando se seleciona somente o recorte urbano. Nesse caso, as unidades contratadas correspondem a $41,2 \%$ do total do déficit habitacional básico urbano paulista para 2010.

Mesmo que as porcentagens ilustrem o quanto ainda está por ser feito, posto que $60 \%$ do déficit básico paulista em 2010 não é solucionado, é inquestionável que foram muitos os esforços e recursos dispendidos nos últimos anos para abrandá-lo (Figuras 3 e 4).

Constata-se que a localização dos empreendimentos respeita, em grande medida, a mesma lógica da 


\section{3}

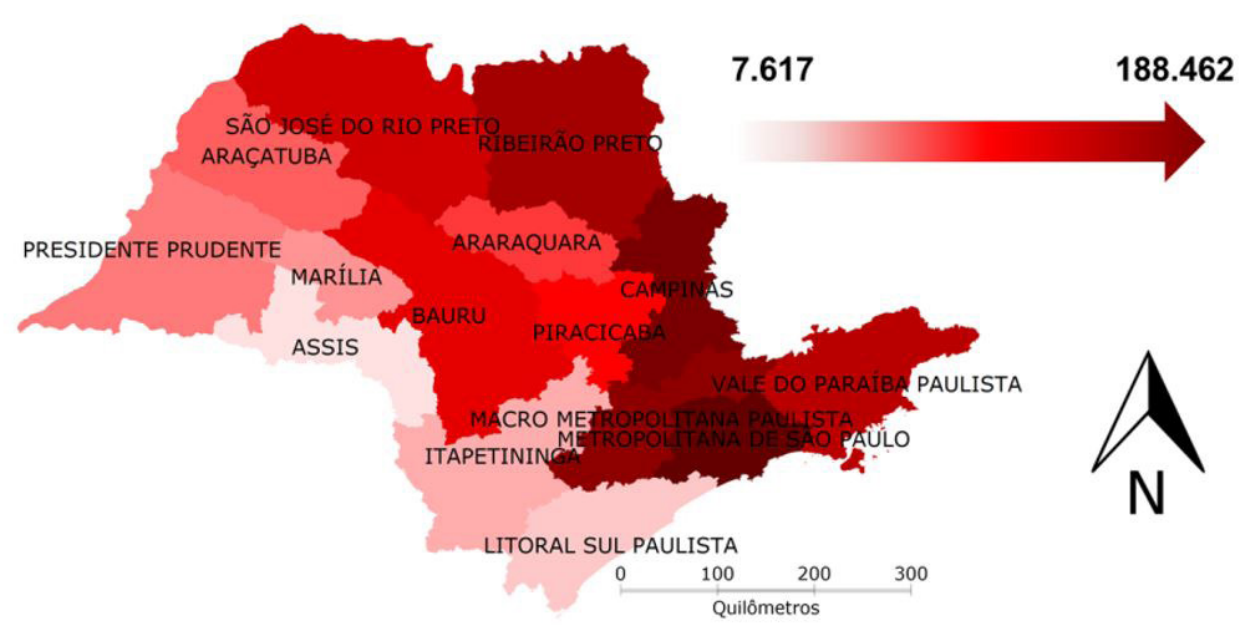

Figura 3 - Total de empreendimentos construídos ou contratados (valores absolutos) segundo mesorregiões paulistas, Estado de São Paulo, 2013 Fonte: IBGE (2005) (Latlong. Datum:SAD69). Escala 1:2.500.000. Elaboração própria.

\section{3}

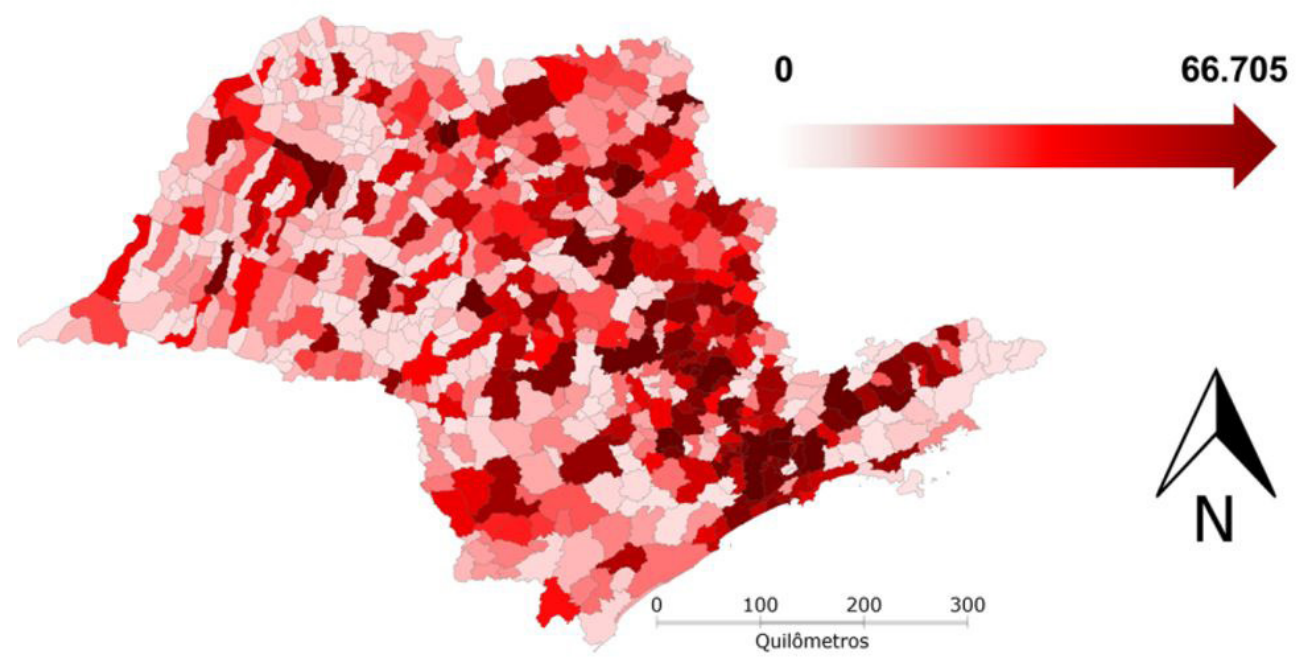

Figura 4 - Total de empreendimentos construídos ou contratados (valores absolutos) segundo municípios paulistas, Estado de São Paulo, 2013 Fonte: BBGE (2005) (Latlong. Datum:SAD69). Escala 1:2.500.000. Elaboracãõo própria.

geografia de posição do déficit. A correlação de Pearson ratifica o pressuposto. A correlação entre déficit e empreendimentos construídos ou contratados pelo PMCMV é de 0,809 com significância de 0,01. Em síntese, a implantação dos empreendimentos é regida pela localização territorial do déficit.

Embora contingente expressivo do déficit persista concentrado e, permanentemente, sendo reproduzido nos grandes centros urbanos (Eixo Campinas-São Paulo-Dutra), a Figura 4 evidencia que o déficit desponta em todo um corolário de municípios intermédios interioranos. Nesta escala de análise, não é possível afirmar que haja uma correlação espacial do déficit. Percebe-se, nesse sentido, que o processo de urbanização se desconcentrou, dispersando-se grandemente pelo interior paulista. Tal contexto trouxe consigo problemas e questões, eminentemente urbanas, como a assincronia entre crescimento urbano-demográfico e a provisão de moradias. 
Deste modo, o índice de Moran Global dos empreendimentos segue a mesma tendência de não correlação espacial do déficit, uma vez que seu produto não ultrapassa 0,15 com também significância de 0,01. Como ambas as dimensões, déficit e empreendimentos habitacionais, estão efetivamente correlacionadas, não é casual que o índice de correlação espacial de Moran siga a mesma tendência de não correlação espacial apresentada do déficit. Entretanto, como elucidado por meio da correlação de Pearson, felizmente a implantação dos empreendimentos do PMCMV é igualmente dispersa no território paulista.

A análise espacial possibilita uma derradeira leitura. Haja vista a sobreposição espacial de ambos os domínios - déficit e empreendimentos - a reprodução e a manutenção do déficit são regidas, segundo outro critério que não o espacial. Neste caso, como até o momento vem sendo discutido, o déficit não atende a contingentes populacionais segundo seu perfil, no caso, sua renda (e não no local em que esta se localiza territorialmente - ao menos segundo esta escala de análise: municípios e Estado). 0 valor da terra e, logo, o valor final da unidade habitacional estão sendo decisivos na marginalização da população de até três salários mínimos do programa.

Por certo, a confluência espacial dos empreendimentos não significou necessariamente efetiva diminuição do déficit nos grandes centros ou, ao menos, dos passivos gerados ao longo de décadas de não política habitacional nestas localidades (Figuras 5 e 6). 0 déficit, também segundo tamanho populacional, perdura.

Os dados demonstram a dificuldade em se resolver os passivos habitacionais acumulados, sobretudo, nas grandes concentrações urbanas, embora estas tenham sido o principal alvo de boa parte dos empreendimentos construídos. Percebe-se, em realidade, que a política habitacional surtiu mais efeito em todo um universo de cidades intermédias do interior paulista (Figuras 7 e 8).

Balbim et al. $(2013,2015)$ apontam uma possível explicação para a desconcentração dos empreendimentos habitacionais em direção a algumas cidades:

[...] faz-se um alerta: ao tratar localizações diferentes como iguais ou similares, a produção habitacional do MCMV em áreas metropolitanas ou municípios conturbados, por exemplo, pode-se viabilizar a geração e incorporação de uma taxa excedente de lucro, pelas construtoras, equivalente à diferença entre o preço de uma "pior" localização, escolhida para a produção de empreendimentos, e o preço de uma "melhor" localização, considerado na composição de custos que definem o limite do valor das UHs pelo programa. (Balbim et al., 2013).

Há, inequivocamente, um efeito de composição, pois há mais empreendimentos Faixa 1 nos municípios em que foram contratados mais empreendimentos, ou seja, nos grandes centros urbanos, sobretudo: Região Metropolitana de São Paulo, Região Metropolitana de

\section{3}

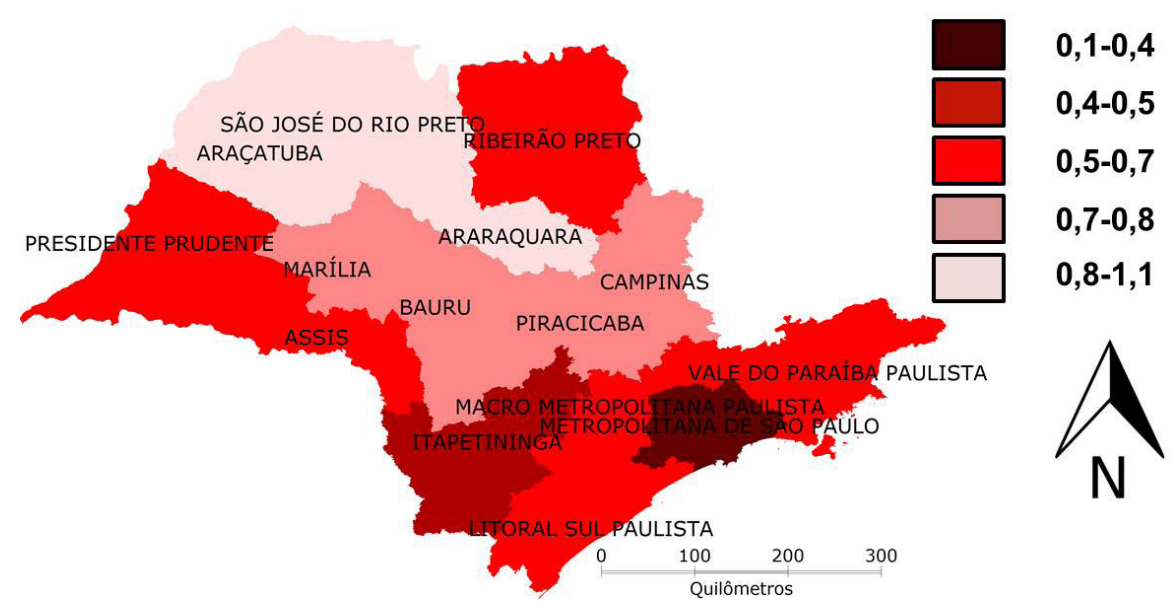

Figura 5 - Razão entre total de empreendimentos construídos ou contratados e déficit habitacional básico total segundo mesorregiões paulistas, Estado de São Paulo, 2013 Fonte: IBGE (2005) (Latlong. Datum:SAD69). Escala 1:2.500.000. Elaboração própria. 


\section{3}

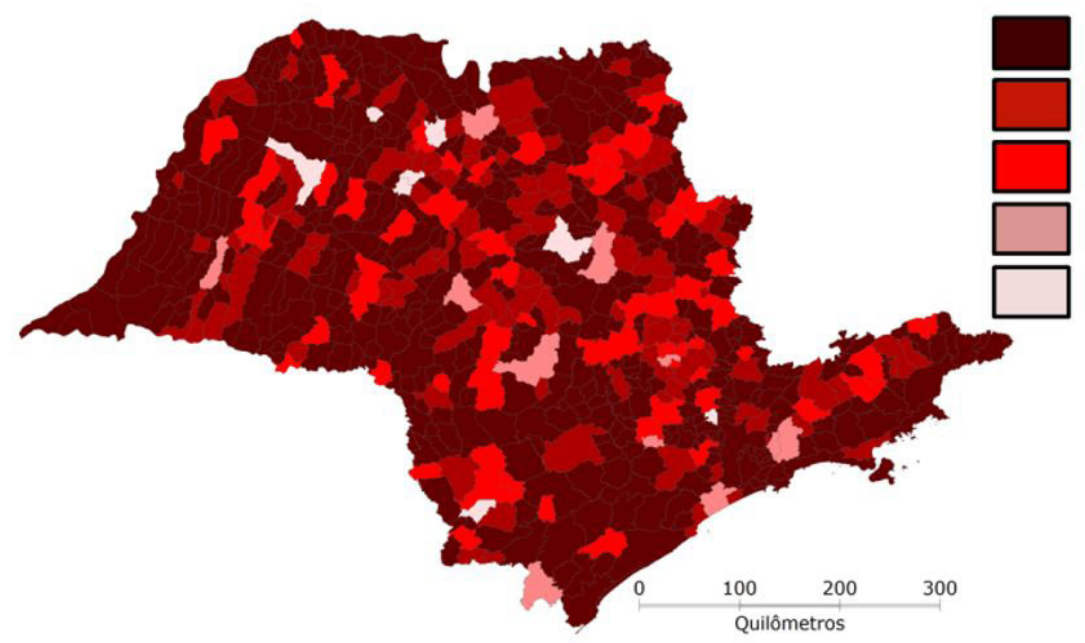

$0.1-0.4$

0.4-0.8

0.8-1.2

1.2-1.6

1.6-2.1

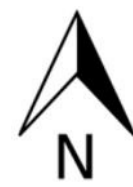

Figura 6 - Razão entre total de empreendimentos construídos ou contratados e déficit habitacional básico total segundo municíios paulistas, Estado de São Paulo, 2013 Fonte: IBGE (2005) (Latlong. Datum:SAD69). Escala 1:2.500.000. Elaboração própria.

\section{3}

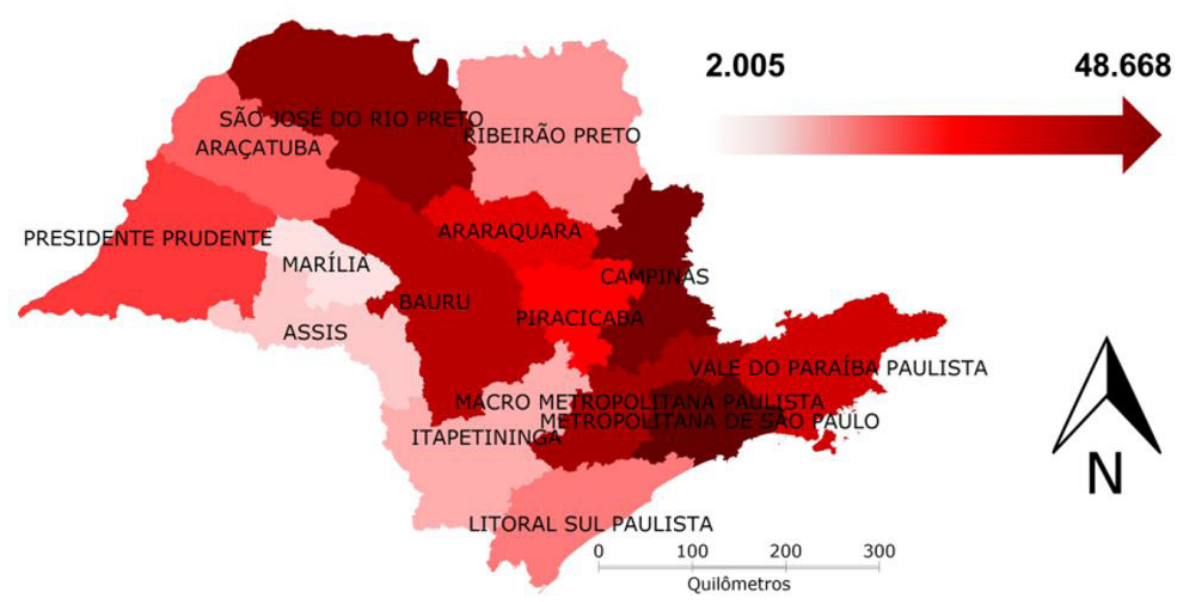

Figura 7 - Tołal de empreendimentos construídos ou contratados faixa 1 (valores absolutos) segundo mesorregiões paulistas, Estado de São Paulo, 2013 Fonte: BBGE (2005) (Latlong. Datum:SAD69). Escala 1:2.500.000. Elaboracãõo própria.

Campinas, Região Metropolitana da Baixada Santista, eixo Dutra e alguns municípios considerados como sede de microrregiões interioranas. Conquanto o déficit persista aí mais agudo. No entanto, como ilustrado pela Figura 8, nota-se que os empreendimentos Faixa 1 construídos e contratados até 2013 nesses municípios pouco ajudam a sanar o problema (Lima et al., 2015).

Como demonstrado na seção anterior, aproximadamente $60 \%$ do déficit habitacional básico paulista é composto por indivíduos e famílias com até três salários mínimos. Entretanto, só 30,5\% dos empreendimentos contratados eram voltados para uma faixa de renda muito semelhante ${ }^{4}$ (Gráfico 9).

\footnotetext{
${ }^{4}$ É preciso lembrar que as faixas de renda do Programa Minha Casa, Minha Vida não são indexadas de acordo com o salário mínimo. Nesse sentido, até 2013 , o teto da faixa 1 já havia sido 2,7 salários mínimos (2010), 2,5 salários mínimos (2011), 2,9 salários mínimos (ainda em 2011), 2,5 salários mínimos (2012) e, por fim, 2,3 salários mínimos em 2013.
} 


\section{3}

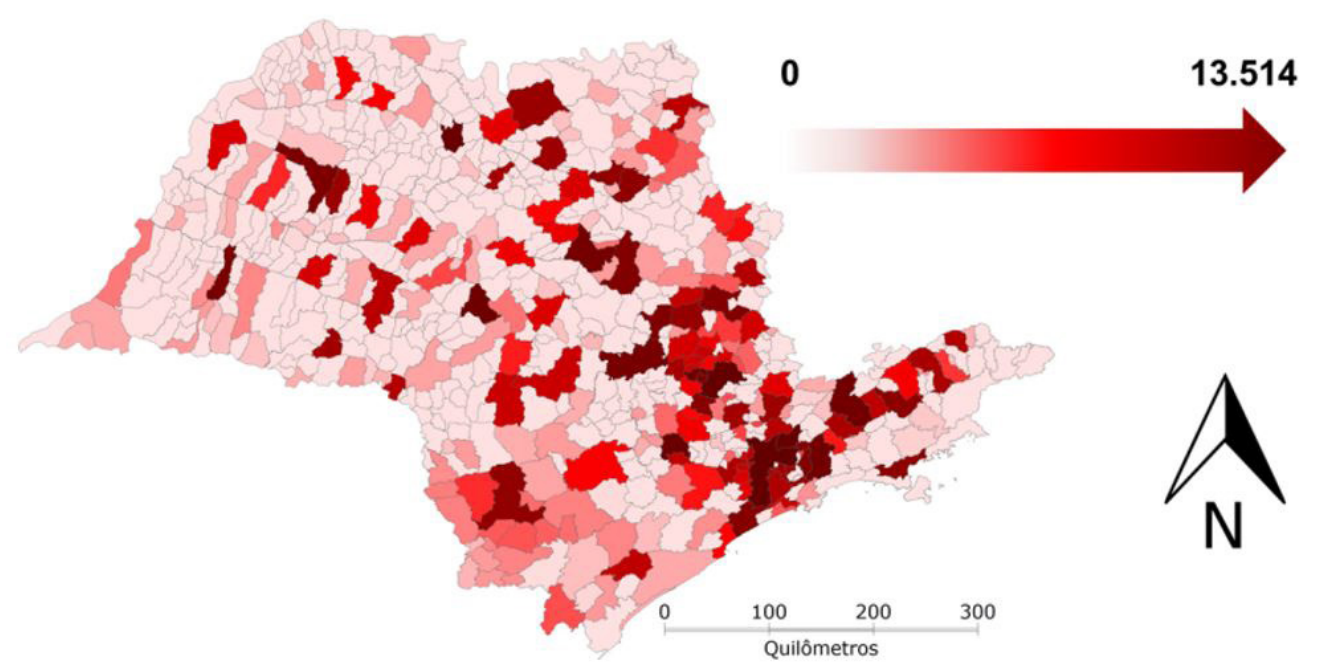

Figura 8 - Total de empreendimentos construídos ou contratados faixa 1 (valores absolutos) segundo municípios paulistas, Estado de São Paulo, 2013 Fonte: IBGE (2005) (Latlong. Datum:SAD69). Escala 1:2.500.000. Elaboracãoo própria.

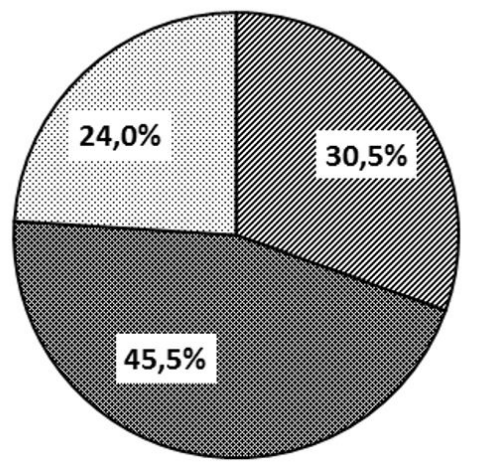

Gráfico 9 - Empreendimentos contratados segundo faixas do PMCMV (I, II e III), São Paulo, 2013

Fonte: Secretaria Nacional de Habitação (SNH), Ministério das Cidades (MC) e Caixa Econômica Federal (CEF). Tabulaçã̃o e elaboraç̣̃o própria.

Curiosamente, os dados demonstram justamente o oposto da demanda real. É dizer, quase $70 \%$ dos empreendimentos paulistas, em 2013, destinaram-se às Faixas 2 e 3 e, somente, $30 \%$ (quando a necessidade era de no mínimo 60\%) para a Faixa 1. Evidentemente, algum público entre 2,3 e 3 salários mínimos foi beneficiado ao longo do período. Contudo, será que foram eles os principais beneficiados?

Essas 184.185 unidades habitacionais contratadas para a Faixa 1 - 30,5\% de moradias contratadas - correspondem a algo como $20 \%(20,7 \%)$ do déficit habitacional básico paulista em 2010 de acordo com faixa de renda muito similar.
Diferentemente do que ocorre com a Faixa 2, esta representa $16 \%$ do déficit habitacional básico paulista, entretanto, $45,5 \%$ das unidades contratadas eram a esta faixa destinadas $(15 \%$ a mais do que para a Faixa 1). Essa quantia dá conta de resolver $87 \%$ dos casos de déficit para esta faixa de renda.

Em suma, falta acurácia ao PMCMV.

\section{Considerações finais}

Em linhas gerais, os dados permitem afirmar que a questão do déficit habitacional brasileiro é ao mesmo tempo crônica, já que persiste há décadas, sendo vista também como aguda, uma vez que se acentua, mesmo com todos os recursos e esforços dispendidos, nos últimos dez anos. Em suma, os programas habitacionais parecem não estar atacando as causas estruturais do problema, ainda que o Plano Nacional de Habitação seja muito didático ao expô-las.

0 déficit aumenta, sobretudo, no ambiente urbano. Afinal, é impossível se desprender do processo histórico de formação de nossas aglomerações urbanas, balizadas por um processo altamente dinâmico, efervescente e repentino de desenvolvimento econômico e industrial, porém desigual e segregatório.

As concentrações e perfis do déficit habitacional básico sugerem a recorrência de desigualdades regionais estruturais. Não se apresenta como fortuito 
que as principais regiões brasileiras, em que o déficit, especialmente segundo renda, se concentra, Nordeste e Sudeste, tenham sido, respectivamente, as principais áreas de origem e destino de fluxos migratórios inter-regionais.

Ao mesmo tempo, a distribuição mais ou menos semelhante da composição do déficit, segundo faixas de renda, independentemente do recorte territorial fossem Unidades da Federação, Grandes Regiões Brasileiras ou mesmo a Nação, que indica que a questão do déficit mais do que um problema territorial é uma questão socioeconômica, em que estratos praticamente inteiros não conseguem adquirir habitação, posto a situação e a condição financeira independentemente do local em que residam.

Tal condicionante sugere que a política habitacional brasileira norteada por mecanismos mercadológicos (financiamentos onerosos, juros, capitalização, valorização, propriedade, etc.) está sendo inócua, quando não agravando o problema ao gerar valorização, especulação e concentração de imóveis e bens nas mãos de alguns poucos, privando outros tantos que, efetivamente, mais carecem dela. Parece importante lembrar que formas cooperativadas de provisão habitacional não representam mais do que 1,8\% dos empreendimentos do Programa Minha Casa, Minha Vida.

0 caso paulista é o retrato deste impedimento, ou melhor, da imprecisão entre público carente e realmente demandante e público de fato atingido.

Ali, enquanto $60 \%$ do déficit é composto por indivíduos e grupos de até três salários mínimos, somente $30 \%$ das unidades contratadas destinavam-se a eles. E estas unidades não representavam mais do que $20 \%$ do déficit, segundo esta faixa de renda.

Diferentemente do que ocorre com a Faixa 2. Assim, este registro representa $16 \%$ do déficit habitacional básico paulista, entretanto, 45,5\% das unidades contratadas destinavam-se a ela (15\% mais do que para a Faixa 1). Incrivelmente, essa quantia dá conta de resolver $87 \%$ dos casos de déficit para esta faixa de renda.

É inegável, portanto, que a política não está atingindo quem mais precisa de moradia.

Ademais, a política pautada na construção de novas unidades, aliada à sua insensibilidade quanto à heterogeneidade de realidades urbanas, estimulou a formação de estoques habitacionais, economicamente valorizados, em cidades médias e não necessariamente nos grandes centros urbanos. 0 preço da terra persiste sendo um empecilho para a edificação de novas unidades habitacionais de interesse social nas grandes cidades. Não é casual que a produção habitacional desta natureza tenha se dispersado em direção a municípios médios e interioranos, conquanto não possamos compreendê-los isoladamente, mas sim como único território contíguo à sede.

O próprio desenho-formato institucional da política e o preço da terra parecem ser os grandes empecilhos para a universalização da moradia como bem e direito. Trata-se de uma miopia. Uma destinação, no mínimo, equivocada dos recursos através de uma forma univariada de provisão habitacional.

A partir dessa perspectiva, o Programa Minha Casa, Minha Vida pode ser encarado como uma política razoavelmente abrangente e diligente. Contudo, parece importante lembrar, que a imensa maioria deste estoque criado não se mantém público ou coletivo (Rizek et al., 2014), mas, sim, transforma-se em propriedade privada, mesmo quando edificado de forma cooperativada. Enfim, o Estado está a todo instante enfatizando o caráter privado da habitação, quando poderia priorizar o direito de uso em detrimento do de propriedade, valendo-se de estoques ociosos. Esta alternativa poderia, inclusive, futuramente regular o preço da terra e da edificação.

Algo poderia ser melhorado por meio da revisão da forma de alimentação do FNHIS e dos mecanismos de funcionamento do SNHIS e, principalmente, com a articulação com os preceitos do Estatuto das Cidades. 0 Estatuto poderia garantir terra urbana financeiramente viável e infraestruturada. Por outro lado, o FNHIS/SNHIS poderia garantir modos cooperativos de construção, relativizando o próprio conceito de propriedade.

Por fim, seria interessante pesquisar os efeitos do programa no ambiente urbano dessas localidades: a associação à dinâmica migratória precedente e vigente segundo as categorias de municípios do PlanHab, variação no estoque de domicílios permanentes e até variação nos indicadores de qualidade de infraestrutura urbana, já que se pressupõe que os empreendimentos tenham um reflexo direto no total de domicílios, que antes compunham aglomerados subnormais. Quiçá, inclusive, em indicadores socioeconômicos, por meio da diminuição da desigualdade. 


\section{Referências}

Amore, C. S., Shimbo, L. Z., \& Rufino, M. B. C. (2015). Minha casa... e a cidade. Avaliação do Programa Minha Casa, Minha Vida em seis estados brasileiros. Rio de Janeiro: Letra Capital.

Azevedo, S., \& Andrade, L. A. G. (2007). Desafios da habitação popular no Brasil: políticas recentes e tendências: habitação social nas metrópoles brasileiras: uma avaliação das políticas habitacionais em Belém, Belo Horizonte, Porto Alegre, Recife, Rio de Janeiro e São Paulo no final do século XX (Coleção HABITARE/FINEP). Porto Alegre: ANTAC.

Balbim, R. N., Krause, L. H., \& Lima, V. C., No. (2013). Minha Casa, Minha Vida, Nosso crescimento: como fica a política habitacional. In Anais do XV Encontro da Associação Nacional de Pós-graduação e Pesquisa em Planejamento Urbano e Regional (p. 1-17). Belo Horizonte: ANPUR.

Balbim, R. N., Krause, L. H., \& Lima, V. C., No. (2015). Para além do Minha Casa Minha Vida: uma política de habitação de interesse social? (Texto para Discussão, No. 2116). Brasília: IPEA.

Bonduki, N. (2008). Política habitacional e inclusão social no Brasil: revisão histórica e novas perspectivas no governo Lula. Revista Eletrônica de Arquitetura e Urbanismo, 1, 70-104.

Brandão, C. (2007). Território \& desenvolvimento: as múltiplas escalas entre o local e o global. Campinas: Editora da Unicamp.

Brasil. (1946, 4 de maio). Lei Federal no 9.218, de 1 de Maio de 1946. Autoriza a instituição da "Fundação da Casa Popular”. Brasília: Diário Oficial da União.

Brasil. (1988, 5 de outubro). Constituição da República Federativa do Brasil de 1988. Brasília: Diário Oficial da União.

Brasil. (2009a, 13 de abril). Decreto $n^{\circ}$ 6.819, de 13 de abril de 2009. Regulament as seções II, III e IV do Capítulo I da Medida Provisória no 459, de 25 de março de 2009, que dispõe sobre o Programa Minha Casa, Minha Vida - PMCMV, a regularização fundiária de assentamentos localizados em áreas urbanas, e dá outras providências. Brasília: Diário Oficial da União.

Brasil. (2009b, 25 de março). Medida Provisória no 459, de 25 de março de 2009. Dispõe sobre o Programa Minha Casa, Minha Vida - PMCMV, a regularização fundiária de assentamentos localizados em áreas urbanas, e dá outras providências. Brasília: Diário Oficial da União.
Brasil. (2009c, 7 de julho). Lei $n^{\circ}$ 11.977/2009, de 7 de julho de 2009. Dispõe sobre o Programa Minha Casa, Minha Vida-PMCMV e a regularização fundiária de assentamentos localizados em áreas urbanas; altera o Decreto-Lei no 3.365, de 21 de junho de 1941, as Leis nos 4.380, de 21 de agosto de 1964, 6.015, de 31 de dezembro de 1973, 8.036, de 11 de maio de 1990, e 10.257, de 10 de julho de 2001, e a Medida Provisória no 2.197-43, de 24 de agosto de 2001; e dá outras providências. Brasília: Diário Oficial da União.

Cardoso, A. L. (2006). Política habitacional no Brasil: balanço e perspectivas. Rio de Janeiro: IPPUR/UFRJ.

Ferreira, J. S. W. (2012). Produzir casas ou construir cidades: desafios para um novo Brasil urbano. São Paulo: FUPAM.

Fix, M. D. A. B. (2011). Financeirização e transformações recentes no circuito imobiliário do Brasil (Tese de doutorado). Programa de Pós-graduação em Economia, Universidade Estadual de Campinas, Campinas.

Fundação João Pinheiro - FJP. Centro de Estatística e Informações. (2001). Déficit habitacional no Brasil 2000. Belo Horizonte.

Fundação João Pinheiro - FJP. Centro de Estatística e Informações. (2011). Déficit habitacional no Brasil 2010. Belo Horizonte.

Georges, I. P., Rizek, C. S., \& Ceballos, M. (2014). As políticas sociais brasileiras: o que há de novo? Caderno CRH, 27(72), 457-461. http://dx.doi.org/10.1590/ S0103-49792014000300001.

Instituto Brasileiro de Geografia e Estatística - IBGE. (2005). Base Cartográfica. Malha Municipal Digital. Projeção Geográfica (LatLong. Datum:SAD69). Brasília: Ministério das Cidades, Secretaria Nacional de Habitação, Caixa Econômica Federal. Elaboração própria. Recuperado em 27 de maio de 2016, de ftp://geoftp.ibge.gov.br/malhas_ digitais/municipio_2005/escala_2500mil/proj_geografica/ arcview_shp/uf/sp/

Kampel, L. C., \& Valle, M. T. M. (1974). Sistema financeiro de habitação. Rio de Janeiro: IBMEC.

Klintowitz, D. C. (2011). Como as políticas habitacionais se inserem nos contextos de reforma do estado? A experiência recente do Brasil. Pensamento \& Realidade, 26(3), 101-120.

Lima, V. C., No., Krause, C., \& Furtado, B. A. (2015). O déficit habitacional intrametropolitano e a localização de empreendimentos do Programa Minha Casa, Minha Vida: 
mensurando possibilidades de atendimento (Avaliação de Políticas Públicas no Brasil, No. 79). Brasília: IPEA.

Manoel, S. K. (2004). Fundação da Casa Popular: projeto frustrado de construção de uma política habitacional no Brasil (Dissertação de mestrado). Escola de Engenharia de São Carlos, Universidade de São Paulo, São Carlos.

Maricato, E. (2003). Metrópole, legislação e desigualdade. Estudos Avançados, 17(48), 151-166. http://dx.doi. org/10.1590/S0103-40142003000200013.

Maricato, E. (2009). Por um novo enfoque teórico na pesquisa sobre habitação. Cadernos Metrópole, 21, 33-52.

Negrelos, E. P. (2014). A moderna habitação econômica como questão de Estado na produção capitalista da cidade. Fases de expansão e redução dos componentes modernos da cidade e da habitação no Brasil - Estado de São Paulo - no período 1930-1986. Urbana, 6(8), 599-625.

Pugh, C. (1991). Housing policies and the role of the World Bank. Habitat International, 15(1), 275-298. http://dx.doi. org/10.1016/0197-3975(91)90020-L.

Pugh, C. (1994). Housing policy development in developing countries: the World Bank and internationalization, 1972-1993. Cities, 11(3), 159-180. http://dx.doi. org/10.1016/0264-2751(94)90057-4.

Rizek, C. S., Santo Amore, C., Camargo, C. M. D., Castro, A. Q. D., Pereira, R. B., Rodrigues, D. P., \& Pereira, M. B. (2014). A inserção urbana através da produção do MCMV-entidades no Estado de São Paulo: abordagem etnográfica de casos selecionados. In Anais do III Encontro da Associação Nacional de Pesquisa e Pós-graduação em Arquitetura e Urbanismo. São Paulo: ANPARQ .

Rolnik, R., \& Klink, J. (2011). Crescimento econômico e desenvolvimento urbano: por que nossas cidades continuam tão precárias? Novos Estudos CEBRAP, 89(89), 89-109. http://dx.doi.org/10.1590/S0101-33002011000100006.

Sánchez, W. M. C. (2013). ¿Derecho a la vivienda, o derecho al crédito para la vivienda? Alegatos-Revista Jurídica de la Universidad Autónoma Metropolitana, 83, 153-168.

Santos, C. H. M. (1999). Políticas federais de habitação no Brasil: 1964-1998 (Texto para Discussão, No. 645). Brasília: IPEA.

Valença, M. M., \& Bonates, M. F. (2010). The trajectory of social housing policy in Brazil: From the National Housing Bank to the Ministry of the Cities. Habitat International, 34(2), 165-173. http://dx.doi.org/10.1016/j.habitatint.2009.08.006.

Vasconcelos, J. R., \& Cândido, J. O., Jr. (1996). O problema habitacional no Brasil: déficit, financiamentos e perspectivas (Texto para Discussão, No. 140). Brasília: IPEA.

Recebido: Jul. 03, 2016

Aprovado: Jan. 26, 2017 